\title{
The Evolution of Marine Reptiles
}

\author{
Ryosuke Motani
}

Published online: 19 May 2009

(C) The Author(s) 2009. This article is published with open access at Springerlink.com

\begin{abstract}
Reptiles have repeatedly invaded marine environments despite their physiological constraints as air breathers. Marine reptiles were especially successful in the Mesozoic as major predators in the sea. There were more than a dozen groups of marine reptiles in the Mesozoic, of which four had more than 30 genera, namely sauropterygians (including plesiosaurs), ichthyopterygians, mosasaurs, and sea turtles. Medium-sized groups, such as Thalattosauria and Thalattosuchia, had about ten genera, whereas small groups, such as Hupehsuchia and Pleurosauridae, consisted of only two genera or less. Sauropterygia and Ichthyopterygia were the two longest surviving lineages, with 185 and 160 million years of stratigraphic spans, respectively. Mesozoic marine reptiles explored many different swimming styles and diets. Their diet included fish, cephalopods, other vertebrates, and hardshelled invertebrates, whereas no herbivore is known at this point. Sauropterygians and ichthyopterygians gave rise to cruising forms that probably invaded outer seas. Intermediate forms that led to the cruising species are known in Ichthyopterygia but not as much in Sauropterygia. Discovery of new fossils should eventually reduce the gap in the fossil record.
\end{abstract}

Keywords Marine reptile $\cdot$ Mesozoic $\cdot$ Plesiosaur . Ichthyosaur $\cdot$ Mosasaur

R. Motani $(\bowtie)$

Department of Geology, University of California, Davis,

One Shields Avenue,

Davis, CA 95616, USA

e-mail: rmotani@ucdavis.edu

\section{Introduction}

The Mesozoic era is often referred to as the Age of Dinosaurs. However, it was not only the dinosaurs that prospered during the time period. The Earth always had more ocean than land. Even so, dinosaurs never became sea dwellers except some birds (birds are a part of dinosaurs). Instead, other groups of reptiles have invaded marine habitats with varying degrees of success many times since the Permian (Carroll 1982), as they still do today. They were successful in becoming marine predators during the Age of Dinosaurs, when there were no mammalian competitors. These groups of sea-going reptiles are collectively called Mesozoic marine reptiles.

More than a dozen groups of marine reptiles are recognized from the Mesozoic (Carroll 1982). Four of them are probably better known than the rest, namely plesiosaurs that are considered to be the model of the imaginary Loch Ness monster (Giles 2006), ichthyosaurs that looked somewhat like a shark or dolphin, mosasaurs that resembled monitor lizards such as the Komodo dragon in some anatomical aspects, and sea turtles that belong to the same lineage as the living forms. Some of them were giants, reaching 20 meters in total length (Nicholls and Manabe 2004), whereas the others were small, reaching only about 40 centimeters (Rieppel 2000). Some were adapted to cruising long distances (Motani 2002a, b), whereas the others were more suitable for ambushing (Massare 1988; O'Keefe 2001).

Reptiles originally descended from early limbed vertebrates that invaded the land about 70 million years before the Mesozoic (Benton 2004). These reptilian ancestors lost their gills at one point in time, so their descendents could not breathe in water unlike fish or some amphibians. They have to come to the water surface to breath the air as they swim, just like humans and dolphins. Such an apparent 
disadvantage, however, did not deter reptiles from reinvading the water.

Reptiles are "cold blooded", i.e., they rely on the heat from external sources (a condition called ectothermic) such as the sun to maintain their body temperature, which fluctuates greatly according to the ambient temperature (a condition called poikilothermy). These physiological traits may appear disadvantageous for living in water because water takes away body heat more efficiently than air. However, reptiles may indeed be more suitable for invading aquatic environment than birds or mammals (Seymour 1982; Brischoux et al. 2008), as long as the surface water temperature is sufficiently high (about $20^{\circ} \mathrm{C}$ ).

Reptiles have at least three advantages over endotherms. First, reptiles are more tolerant of lower body temperatures. The pelagic sea snake Pelamis, for example, can tolerate body temperatures between $18^{\circ} \mathrm{C}$ and $33^{\circ} \mathrm{C}$ (Graham 1974), whereas most mammals would not be able to survive such low body temperatures. Marine mammals maintain much higher body temperatures, between $35^{\circ} \mathrm{C}$ and $39^{\circ} \mathrm{C}$, regardless of the ambient temperature (Whittow 1987) by spending extra energy. Second, reptilian physiology has an advantage of "fuel efficiency." Thanks to their slower metabolic rates, reptiles consume much less oxygen per second than mammals do, which in turn means that they can do without breathing for a longer time given the same amount of oxygen stored in the body. Third, they can tolerate anoxia better in case of oxygen shortage. These characteristics enable reptiles to stay longer in water than mammals of equal body mass on average.

The purpose of this contribution is to review the evolution of marine reptiles with emphasis on Mesozoic forms. It is beneficial to learn from living species first, so I will start by briefly reviewing extant marine reptiles.

\section{Definition of Marine Reptiles}

It is firstly important to define the phrase "marine reptile." Each of the two words requires clarification to avoid confusion. First, the word "marine" is restricted to those vertebrates that feed almost exclusively in the sea in this contribution. This is stricter than the more common usage where any vertebrate that spends time at sea at all is included. The restricted usage is preferred here to remove ambiguity. About 250 species of extant reptiles live in haline habitats or occasionally invade them (Wilfred 1958). Extreme examples are large reptiles in the Southeast AsiaAustralia, namely the saltwater crocodile (Crocodylus porosus), Asian water monitor (Varanus salvator), and reticulated python (Python reticulatus). They can swim across long distances in the ocean (e.g., Rosenzweig 2001; Borden 2007) and at least the crocodile and monitor lizard may even feed on fish, but they spend most of their time in other places through a year. The saltwater crocodile especially is often considered marine, but it is unclear whether it is more marine than the Asian water monitor, which is seldom called marine. The restricted usage of "marine" in this contribution would remove all of these ambiguous animals from consideration as marine reptiles.

Second, the word "reptile" is restricted to those vertebrates that are called reptiles in common English (i.e., "lizards," snakes, tuataras, crocodiles, and the fossils related to them). Birds are descendants of some reptiles, so they are reptiles themselves in a strict sense. However, inclusion of birds, which are warm-blooded, would obscure the discussion. I therefore remove birds from "reptiles" in this contribution. In summary, "marine reptiles" in the current context are all reptiles except birds that feed almost exclusively in the sea.

\section{Living Marine Reptiles}

Four lineages of living reptiles are considered marine in this review but only one of them is fully aquatic. The four are true sea snakes (about 50 species), sea turtles (eight species), sea kraits (second lineage of sea snake-about five species), and the marine iguana (Márquez 1990; Rasmussen 2001). Note that the saltwater crocodile, which is sometimes considered a marine reptile, is not included among marine reptiles here, as discussed above. The true sea snakes are the only lineage that almost never leaves the water - they even give live birth in water (Rasmussen 2001). Sea kraits, on the other hand, spend more time on land than at sea (Brischoux et al. 2008). However, they are very capable of swimming, diving to about 80 meters during their hunting trips. They capture their prey in the sea but rest on land to digest it. Sea turtles are almost fully aquatic but at least females still need to return to land to lay eggs.

Living marine reptiles are tropical to subtropical in their distribution, except for some sea turtles that are distributed into the colder waters, such as the gigantic leatherback turtle (Márquez 1990). This is in contrast to marine mammals, some of which tend to exclusively occupy high latitudes (Jefferson et al. 1993). The difference ultimately comes down to their physiology. Reptiles are ectothermic and have difficulty sustaining a minimally required body temperature (about $18^{\circ} \mathrm{C}$ ) in cold waters unless the body is adapted to slow down the cooling through, for example, having extra insulation and large body size as in large sea turtles. This prohibits small marine reptiles from moving between the Pacific and Atlantic oceans. A good demonstration of this constraint is the geographic distribution of sea snakes. Sea snakes are not known from the Atlantic, although at least one of them is pelagic and therefore is capable of swimming that far (Graham et al. 1971). Sea 
turtles, on the other hand, are capable of swimming around South Africa to move between oceans.

\section{Mesozoic Marine Reptiles}

At least a dozen groups of marine reptiles can be counted in the Mesozoic fossil record, containing a minimum of 250 genera. Four major groups are Sauropterygia (Fig. 1b, c), Ichthyopterygia (Fig. 1e), Mosasauridae (Fig. 1a), and Chelonioidea (sea turtles; Fig. 1d), all of which have about 30 genera or more (Table 1). Four other groups, namely Thalattosauria (Fig. 1f), Thalattosuchia, and two groups of turtles, were medium sized, each containing about ten genera. The rest of the groups were smaller, with five or less genera per group.
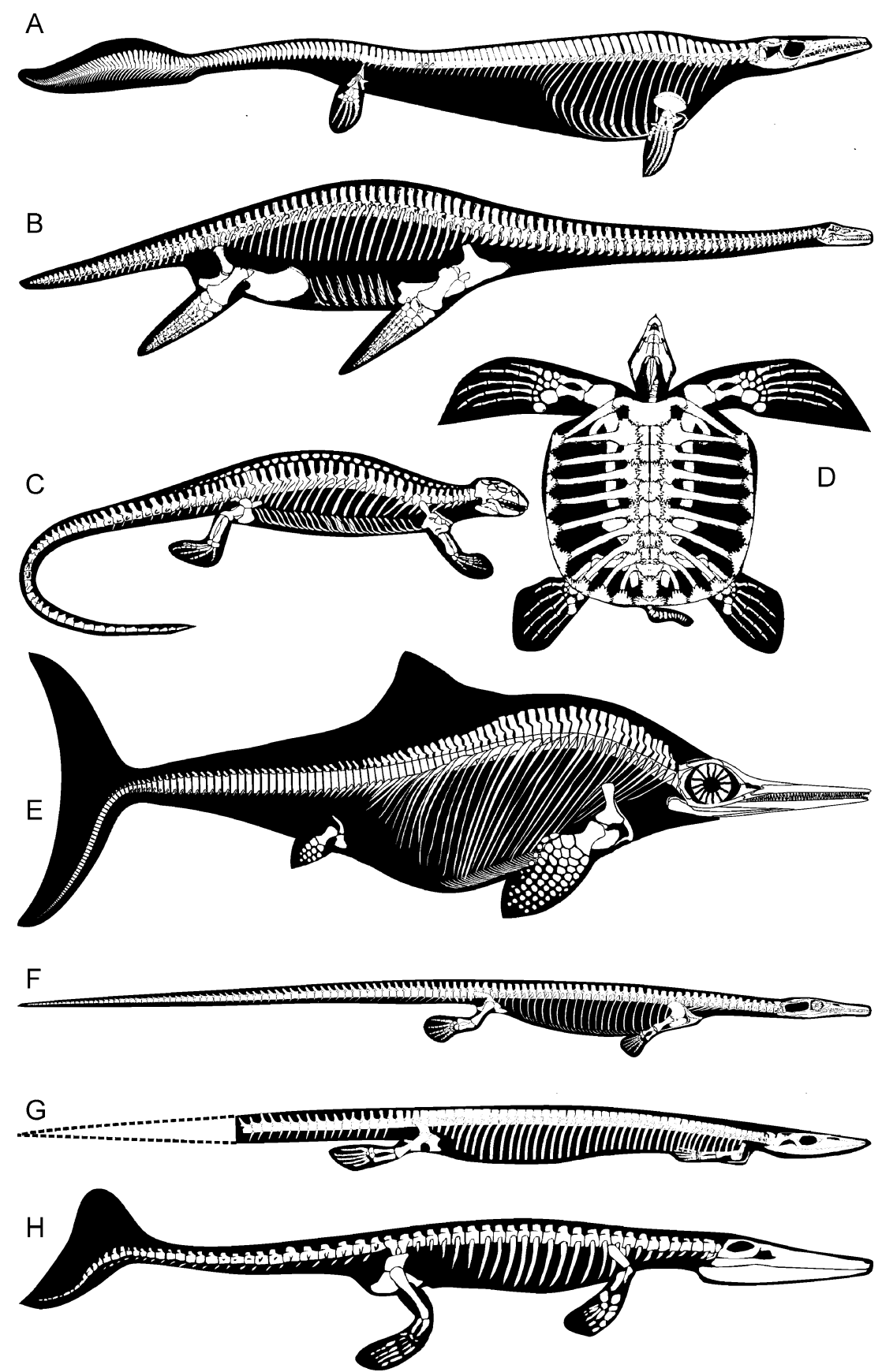

Fig. 1 Body shapes of selected Mesozoic marine reptile groups. a Plotosaurus (mosasaur); b Muraenosaurus (plesiosaur); c Placodus (placodont); d Archelon (sea turtle); e Ophthalmosaurus (ichthyopterygian); f Askeptosaurus (thalattosaur); g Pleurosaurus (pleuro- saurs); h Metriorhynchus (thalattosuchian). a-g Modified from Camp (1942), Andrews (1910), Carroll (1988), Wieland (1909), McGowan and Motani (2002), Kuhn-Schnyder (1952), Carroll (1985), and Hua and Buffrenil (1996), respectively. Body outlines are inaccurate 
Table 1 Generic diversity of Mesozoic and extant marine reptile groups

\begin{tabular}{|c|c|c|c|}
\hline Time & Group & (Subgroup) & Generic diversity \\
\hline \multirow[t]{4}{*}{ Extant } & Sea snake & & 16 \\
\hline & Sea turtle & & 6 \\
\hline & Sea krait & & 1 \\
\hline & Marine iguana & & 1 \\
\hline \multirow[t]{16}{*}{ Mesozoic } & Sauropterygia & Placodontia & ca. 10 \\
\hline & & Plesiosauria & ca. 70 \\
\hline & & Others & ca. 20 \\
\hline & Ichthyopterygia & & ca. 40 \\
\hline & Mosasauroidea & Mosasauridae & ca. 30 \\
\hline & & Others & ca. 10 \\
\hline & Marine snakes* & & ca. 5 \\
\hline & Chelonioidea & & ca. 30 \\
\hline & Thalattosauria & & ca. 10 \\
\hline & Thalattosuchia & & ca. 10 \\
\hline & Marine Pleurodira & & ca. 10 \\
\hline & Marine Cryptodira & & ca. 10 \\
\hline & Pleurosauridae & & 2 \\
\hline & Hupehsuchia & & 2 \\
\hline & Qianosuchus & & 1 \\
\hline & Sikannisuchus & & 1 \\
\hline
\end{tabular}

*different from living sea snakes

Two of the four major groups appeared in the Early Triassic (Rieppel 2000; McGowan and Motani 2002), whereas the others are first recorded from the Early (Chelonioidea) and Late (Mosasauridae) Cretaceous (Hirayama 1998; Jacobs et al. 2005). The groups that emerged in the Jurassic, namely Pleurosauridae (Fig. 1g), Thalattosuchia (Fig. 1h), and two groups of turtles, were less successful. Sauropterygians and ichthyopterygians survived the longest by lasting for more than 150 million years each. Sea turtles are also successful, having survived for the last 120 million years. Moderately long-lasting groups, such as mosasaurs, thalattosaurs, and thalattosuchians, existed for about 30 to 60 million years each. The shortest-lasting group included Hupehsuchia, which is known only from the Spathian (late Olenekian, Lower Triassic), probably not representing much more than a few million years.

A simple plot of stratigraphic ranges of Mesozoic marine reptile groups reveals a pattern (Fig. 2). That is, new groups seem to emerge after previous occupants of the niche became extinct. For example, the Early Jurassic saw the invasion of the sea by thalattosuchians and pleurosaurs, and this was some time after most of the coastal marine reptiles of the Triassic became extinct. The two groups became extinct in the Early Cretaceous, some time before mosasaurs and sea turtles appeared. The highest diversity of marine reptiles was achieved in the Triassic.
Different groups of Mesozoic marine reptile adopted different swimming styles. Plesiosaurs and sea turtles used their limbs to fly underwater (Massare 1988), whereas the other groups used their body axis, especially the tail, for propulsion. Early eosauropterygians that led to plesiosaurs probably used the limbs for propulsion (Rieppel 2000), but it is possible that the tail was also used in conjunction. Based on analysis of their teeth (Massare 1987), their diets varied greatly. Some Mesozoic marine reptiles were probably pursuit predators eating fish, cephalopods, and other reptiles, whereas the others ate benthic prey, such as hard-shelled invertebrates (Massare 1987, 1988). It is also possible that soft-bodied invertebrates, such as polychaete worms, were eaten by marine reptiles, but they are not known in the stomach regions of marine reptiles fossils

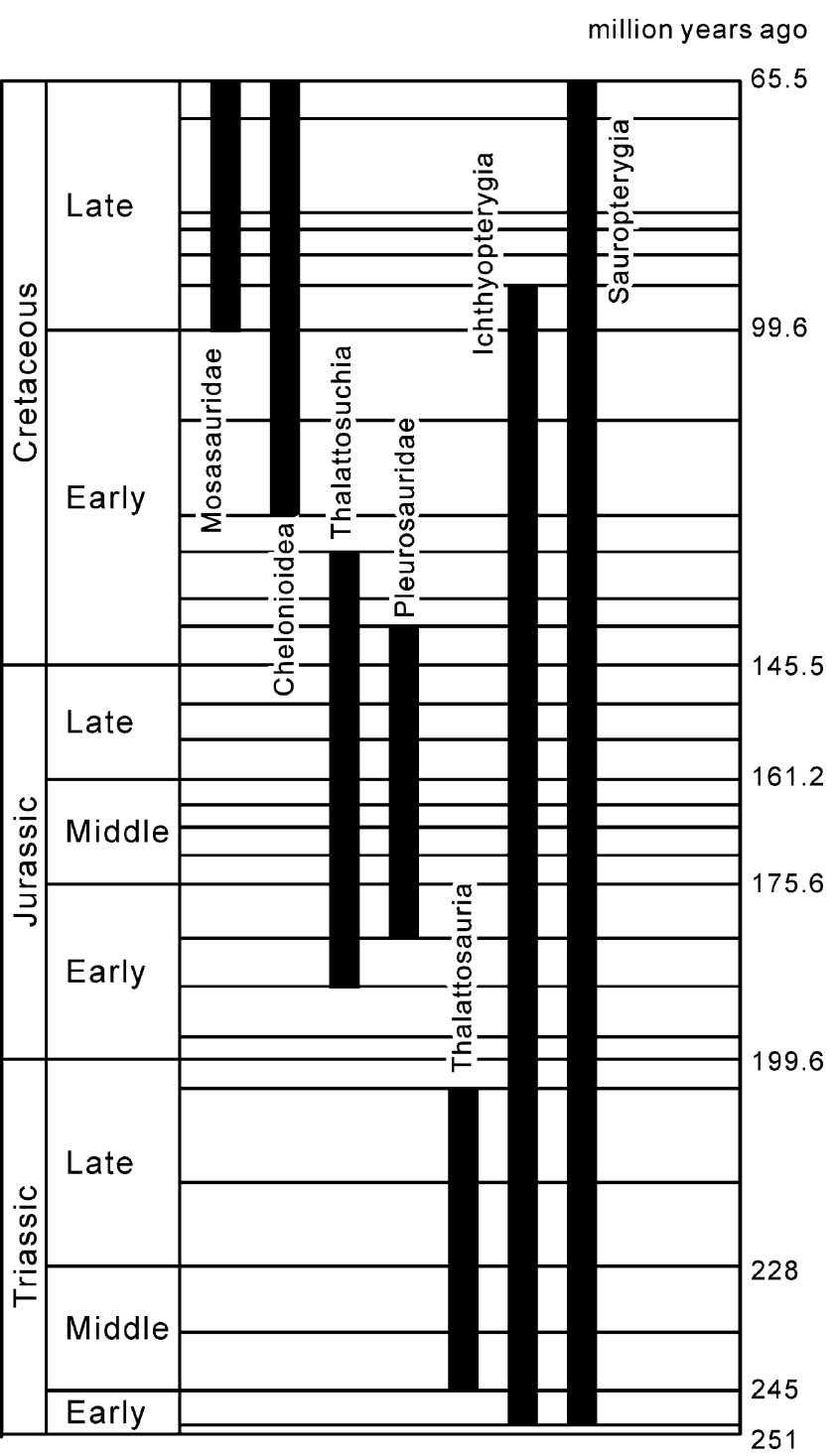

Fig. 2 Stratigraphic ranges of selected Mesozoic marine reptile groups 
probably because they rarely are preserved as fossils. There is no record of herbivorous marine reptiles in the Mesozoic, unlike in extant marine reptiles (i.e., marine iguana is an herbivore).

The reproductive biology of Mesozoic marine reptiles is partly known. Fossil evidence for live birth is present at least for sauropterygians, ichthyopterygians, and mosasaurs (e.g., Brinkmann 1998; Caldwell and Palci 2007). However, how prevalent this feature was within each group is not necessarily well known, as will be reviewed for each group. Live birth is probably a useful feature for marine reptiles but not essential for invading marine environments - three of the four living marine reptile lineages lay eggs on land, and there is no evidence to suggest that the most basal members within each Mesozoic marine reptile group, including sauropterygians and ichthyopterygians, gave live birth, except for mosasaurs. Live birth is probably even more useful to pelagic marine reptiles. However, one counterexample demonstrates that it is not a necessary condition — sea turtles invade pelagic environments yet they lay eggs.

I will now review representative groups of Mesozoic marine reptile in the following sections.

Sauropterygia (Including Plesiosauria)

This is by far the largest group of Mesozoic marine reptiles, containing two major lineages (Rieppel 2000), namely placodonts and eosauropterygians (Fig. 3). The two had very different body designs. Placodonts were short-necked animals with short and robust skulls, whereas eosauropterygians had a long neck that ends with a narrow skull that is usually small relative to the total length of the animal. At the same time, both shared certain features, such as the unique design of the shoulder girdle where the clavicles are located medial to the scapula. Other similarities include the absence of lacrimal bone and the extreme reduction of carpals and tarsals (wrist and ankle).
Fig. 3 Stratigraphy and relationships of major groups of Sauropterygia. There is a large gap in the fossil record along the line leading to Plesiosauria

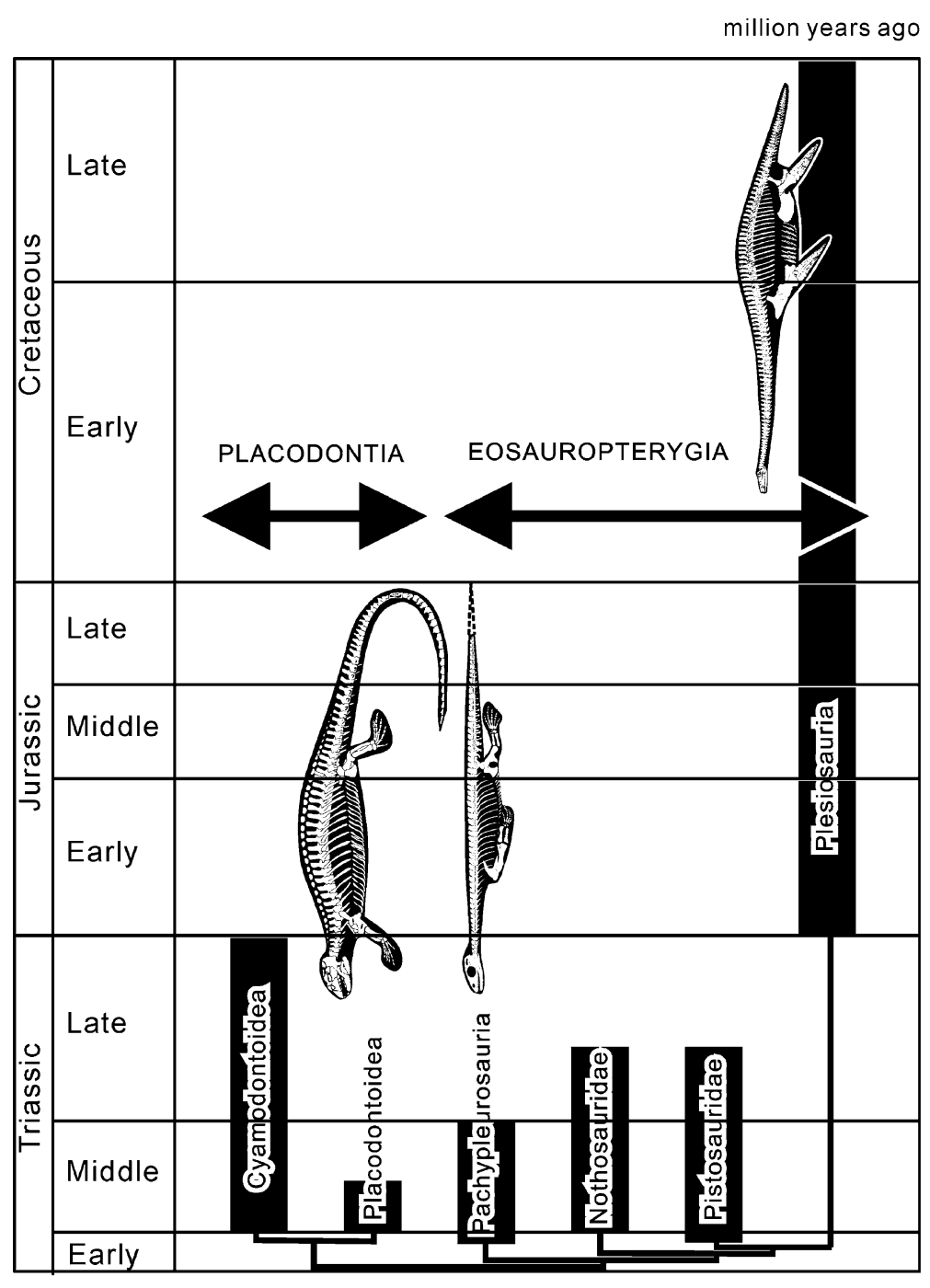


Placodonts were geographically restricted to the Tethys Sea and chronologically to the Triassic, although a single new fossil may alter our view. Indeed, they were thought to have been restricted to the Western Tethys a decade ago but new fossils from Guizhou, China changed this view early in this century ( $\mathrm{Li}$ and Rieppel 2002). The oldest fossils of placodonts come from the lower Muschelkalk of Germany, which was once believed to extend back to the Lower Triassic. However, this view has been questioned based on a global correlation (Kozur and Bachmann 2005). Therefore, we currently do not have a definitive record of placodonts from the Lower Triassic.

Most placodonts had flattened teeth on the palate and the jaw margin, suggesting durophagy (i.e., diet on hard-bodied prey). Placodonts are divided into two groups based on the presence/absence of the body armor comprising a carapace (or an anterior and a posterior carapaces in some taxa). Those with a body armor are called cyamodontoids, whereas those without are named placodontoids. Even placodontoids, however, may have extra bones in the skin along the top of the vertebral column, comprising a limited "armor." Cyamodontoid body armor superficially resembles that of turtles. Given this similarity, together with their occurrence in the Triassic of Germany where earliest turtles are found, it has been suspected that they may be related to the turtles. However, this putative relationship has been refuted more recently based on detailed anatomical and histological comparisons (Rieppel 2000; Scheyer 2007).

Eosauropterygians, in contrast to placodonts, were widespread both geographically and temporarily. They were the longest-ranging group of marine reptiles. They appeared before the end of the Early Triassic (Storrs 1991; $\mathrm{Li}$ 2002) and already had a wide distribution in the Northern Hemisphere (USA and China). The lineage lasted until the end of the Cretaceous, when dinosaurs and many other organisms became extinct (also known as $\mathrm{K} / \mathrm{T}$ extinction because it is at the boundary between Cretaceous and Tertiary). This amounts to about 185 million years (Fig. 3).

Fig. 4 Two typical body plans in plesiosaurs scaled according to trunk lengths. a Long-necked elasmosaur, modified from Carroll (1988); b short-necked pliosaurs based on Tarlo (1960)
Plesiosaurs are the most derived clade (natural group) of eosauropterygians (Fig. 3). They are essentially different from all other eosauropterygians in several respects. First, they are unknown before the Jurassic, whereas the other eosauropterygians are only known from the Triassic (Fig. 3). It has been argued that some English plesiosaurian fossils may have come from the highest Triassic strata but this view has been questioned (Hesselbo et al. 2004). Second, their limbs had been modified into rigid flippers. The largest difference between the limbs of plesiosaurs and other eosauropterygian is found in the structure of the wrist and ankle. These areas are well ossified in plesiosaurs, i.e., bones in the areas are large and tightly integrated with each other, whereas they remained highly cartilaginous in other eusauropterygians, i.e., some bones floated within the mass of cartilage. The palm/foot and finger bones were also tightly packed in plesiosaurs, whereas they retained much space in-between in other eusauropterygians. The differences suggest that plesiosaurs probably used their flippers for swimming more rigorously than in other eosauropterygians. Plesiosaurs are known from every continent including Antarctica, unlike more basal eosauropterygians.

Two extreme body designs are recognized among plesiosaurs (Fig. 4). They are often referred to as shortand long-necked plesiosaurs, or pliosauromorph and plesiosauromorph designs (O'Keefe 2002). Short-necked plesiosaurs have a relatively short neck and large head compared to the total length of the animal, whereas the situation is reversed in long-necked plesiosaurs. Note that even the short-necked plesiosaurs had a long neck relative to the total length by reptilian standards. Among the plesiosauromorph plesiosaurs, the Cretaceous Elasmosauridae is well known for extremely long necks. For example, the skull is only about half a meter in an elasmosaurid of about ten meters in total length, whereas it could be longer than two meters in a large short-necked plesiosaur of a similar length. The neck of this short-necked plesiosaur is about two meters or less, whereas it could be as long as about six meters in its elasmosaurid counterpart. There is a controversy on whether 
pliosaurs and plesiosaurs represent different taxonomic groups (Druckenmiller and Russell 2008).

Different lifestyles have been inferred for long- and short-necked plesiosaurs. It is generally believed that shortnecked plesiosaurs were capable of pursuit hunting, whereas long-necked forms probably used less swimming during prey capture (O'Keefe 2002; O'Keefe and Carrano 2005). However, there has not been a consensus on how the very long neck may have been used by the long-necked plesiosaur, or how flexible it may have been in life. A rigorous examination of the neck structure is necessary. It is important to note that there were species that are intermediate between long- and short-necked designs (O'Keefe 2002). These forms may or may not have been intermediate between the two extremes in terms of lifestyle.

Fossil evidence of live birth is known among Pachypleurosauridae. The best examples are the specimens of Keichousaurus from Guizhou, China, described by Cheng et al. (2004) - curled-up embryos were found inside of adults. It is also said that a plesiosaur specimen that contains embryos inside the body exists. Outside Pachypleurosauridae, evidence of live birth is unknown for basal members of sauropterygians, such as placodonts and Wumengosaurus (Jiang et al. 2008). It is therefore unknown if all sauropterygians gave live birth, or if the first sauropterygians was a live bearer.

There are many other questions to be answered regarding the evolution and ecology of sauropterygians. For example, the lineage that led to Plesiosauria has a large gap in the fossil record in the Upper Triassic (Fig. 3) - the youngest record is from the lower Carnian (Dalla Vecchia 2006), leaving the rest of the Carnian as well as the Norian and Rhaetian without a fossil for this lineage. This gap needs to be closed through discoveries of intermediate specimens. Also, the presence of two contrasting body designs among sauropterygians (i.e., placodonts and eosauropterygians) poses a question about their common ancestor-which body style did it have? The answer is currently unknown, but new fossils from southwestern China, especially Guizhou and Yunnan Provinces, may shed some lights on this issue in the future.

\section{Ichthyopterygia}

Ichthyopterygians are the second largest group of Mesozoic marine reptiles and produced some of the largest individuals. They are also the second in terms of the duration of their existence - they appeared in late Early Triassic and became extinct in the early Late Cretaceous (Fig. 2). This amounts to about 160 million years-approximately 25 million years shorter than the span of eosauropterygians.

Ichthyopterygians are known for the evolution of a fishshaped body profile among their derived members
(Fig. 1e). The name Ichthyosauria, which is a subgroup of Ichthyopterygia, literally means "fish-lizard." The fishshaped ichthyopterygians form a group called Parvipelvia, meaning a small pelvic girdle. The most visible characteristic of the fish shape is the presence of a crescent-shaped caudal fluke. Only the ventral lobe of the caudal fluke is supported by the vertebral column (Fig. 5), leaving the dorsal lobe without any hard tissue. The dorsal lobe therefore is usually unpreserved in fossils. When parvipelvians were first discovered in the first half of the nineteenth century, the crescent-shaped caudal fluke was not properly recognized because of the absence of preserved dorsal lobe. Thanks to the preserved outline of caudal fluke soft tissues in exceptional specimens that we know the presence of the caudal fluke. Approximate outlines of the caudal fluke are now known for at least three parvipelvian genera (Bardet and Fernández 2000; Martill 1995; Fraas 1892), namely Ichthyosaurus (Early Jurassic of England), Stenopterygius (Lower Jurassic of Germany), and Aegirosaurus (Upper Jurassic of Germany).

Many air-breathing vertebrates have become secondarily aquatic (e.g., marine mammals and reptiles), but there have been only two examples of their evolving fish-shaped body profile. The other example is whales (including dolphins). Given that whales did not evolve until after the Mesozoic, ichthyopterygians were the first air-breathing vertebrates to give rise to fish-shaped body outline.

The evolution of fish shape in ichthyopterygians is still being studied, but several key factors are already known (Fig. 5). First, early ichthyosaurs were not fish-shaped. The most famous example is Chaohusaurus from the Lower Triassic of China (Motani et al. 1996), which had an appearance of a "lizard with flippers," as one would expect for a reptile that invaded the ocean not long ago. Second, the truly fish-shaped ichthyosaurs (i.e., parvipelvians) existed as early as the Norian (Late Triassic), as seen in Hudsonelpidia (McGowan 1995) and Macgowania (McGowan 1996). This leaves about 30 million years between the invasion of the sea by early ichthyopterygians and the appearance of the true fish-shaped ichthyopterygians. Third, some Carnian (Late Triassic) ichthyopterygians, such as Guanlingsaurus, represent intermediate stages between lizard- and fish-shaped ichthyopterygians (Motani 2008). However, it is unknown at this point if the evolution of fish shape proceeded with a constant pace or not. Further studies of Triassic ichthyopterygians are necessary to clarify the tempo and mode of the fish shape evolution.

Ichthyopterygians have several noteworthy records apart from being the first tetrapod to become fish-shaped. First, they had the largest eyes of all vertebrates, sometimes exceeding 25 centimeters in diameter (Motani et al. 1999). The unusual size of ichthyopterygian eyes may be illuminated by the fact that the largest vertebrate eyes 
Fig. 5 Stratigraphy and relationships of major groups of Ichthyopterygia. Evolution of fish shape is illustrated by many intermediate forms

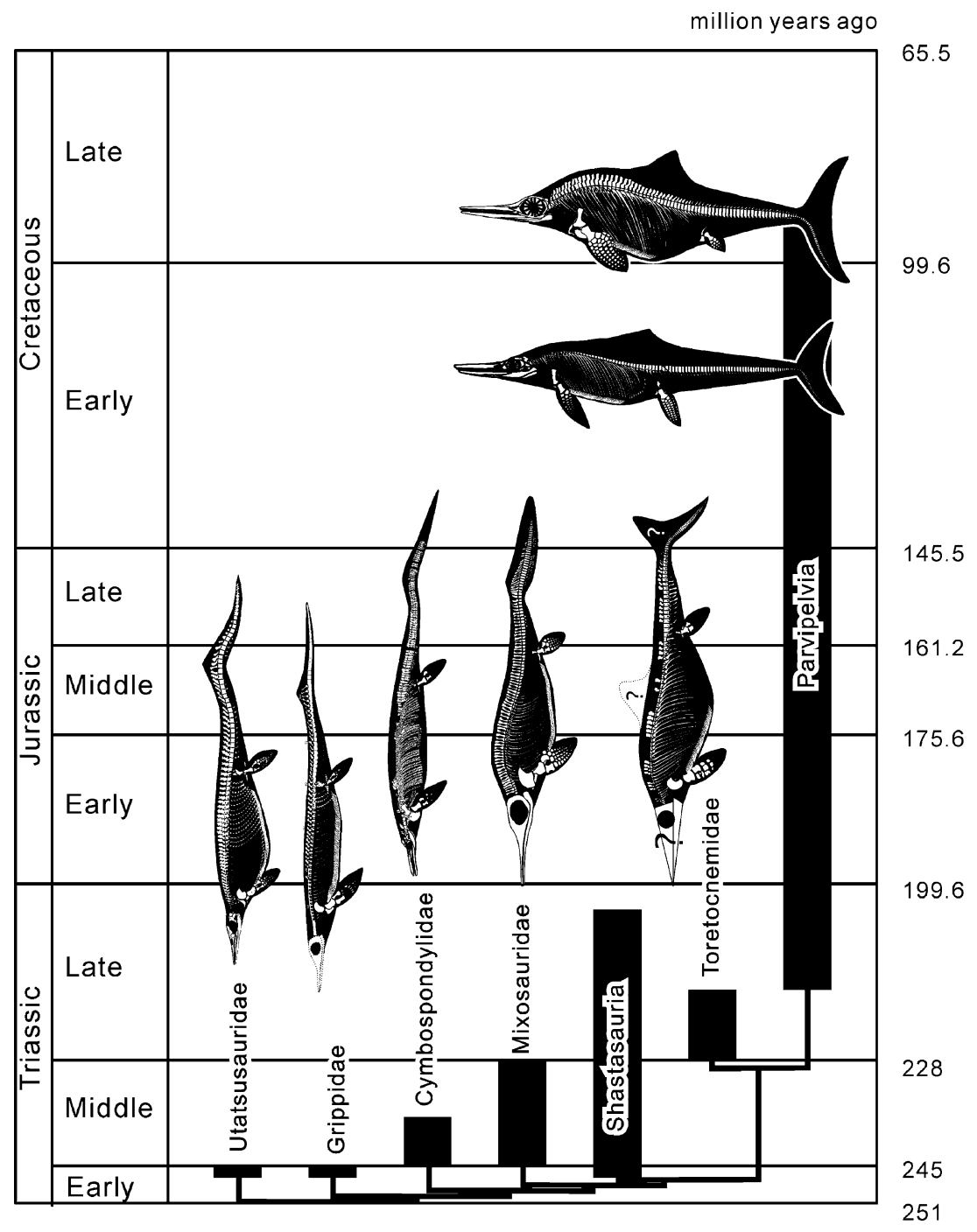

outside of Ichthyopterygia is only about 15 centimeters across although they belong to the largest vertebrate in history-the blue whale (Walls 1942). Second, some ichthyopterygians had the highest finger count among vertebrates. Caypullisaurus (Fernández 2001), for example, probably had up to ten digits per manus.

The largest eyes among ichthyopterygians are found in fish-shaped forms-lizard-shaped forms had reasonably large eyes for vertebrates but smaller than those in fishshaped forms. Therefore, the enormous eyes evolved in conjunction with the fish-shaped body profile (Motani 2008). These enormous eyes were adapted for low-light environments. Motani et al. (1999) estimated the f-numbers of ichthyopterygian eyes and found that the values for fishshaped ichthyopterygians were lower than those of lizardshaped forms (note: the lower the f-number, the more sensitive is the eye to low levels of light). The lowest fnumber found among fish-shaped ichthyopterygians rivaled the values found in nocturnal mammals, such as rats and cats (about 1.0), whereas other fish-shaped ichthyopterygians had slightly higher values of up to about 1.5, resembling the values of animals active in the dusk (i.e., crepuscular) or both night and day (i.e., cathemeral). Lizard-shaped ichthyopterygians, on the other hand, had f-numbers similar to those of diurnal mammals (about 2.0).

The sensitive eyes of parvipelvians are unlikely to be an adaptation for nocturnality. Ichthyopterygians started to give live birth at least as late as in the Anisian (Middle Triassic), soon after their emergence in the late Early Triassic. This presumably suggests that they started to spend their entire life in water (i.e., fully aquatic). It is then most likely that they were engaged in hemispheric sleepthe strategy seen in many vertebrates including dolphins where one side of the brain sleeps at a time, enabling the animal to stay alert all the time. This is particularly important for avoiding drowning in fully aquatic air breathers. This means that ichthyopterygians were adapted to seeing during the night long before the parvipelvians 
appeared. Then, the enhanced visual sensitivity seen in parvipelvians probably suggests that they used their eyes to see in the darkness of the depth.

The correlated evolution of fish shape and dark-adapted eyes in ichthyopterygians suggests that parvipelvians had the ability not only to cruise fast and far but also to dive more deeply than in lizard-shaped ichthyopterygians. This combination indicates an adaptation to pelagic life, so it is likely that ichthyopterygians invaded the pelagic realms by the time parvipelvians appeared (Motani 2008). This does not mean that all parvipelvians were pelagic: many small cetaceans stay in the coastal water today whereas the others are pelagic. Ichthyopterygians were already widespread across the Northern Hemisphere in the Early Triassic. They are also found in the Southern Hemisphere by the Late Triassic. It seems as if they emerged in the Northern Hemisphere, but further research on the Lower and Middle Triassic of the Southern Hemisphere may reveal ichthyopterygians there.

The evidence of live birth is abundantly known among ichthyopterygians. The most basal ichthyopterygians to show the evidence is the Middle Triassic Mixosaurus (Brinkmann 1998), and many of the more derived ichthyosaurs are known to have embryos inside the body of adults (e.g., Woodward 1906; Dal Sasso and Pinna 1996). However, no evidence exists on the reproductive biology of the most basal ichthyopterygians, such as Utatsusaurus, Grippia, and Chaohusaurus. It is therefore unknown, as in sauropterytians, if all ichthyopterygians were live bearers, or if they were already giving live birth when they invaded the marine environments.

One of the largest questions that remain is the reason for the extinction of ichthyopterygians. No ichthyopterygian fossil record exists after the Cenomanian (about 90 million years ago), so it is possible that they became extinct coinciding with the Cenomanian-Turonian extinction event (Bardet 1992). However, Cretaceous ichthyosaurs were most likely generalized feeders (Kear et al. 2003) that were not dependent upon a single food source, so disappearance of prey during the Cenomanian-Turonian event does not seem to constitute a reasonable explanation of their extinction. Cretaceous ichthyopterygians are generally understudied, so it is important to accumulate more data on this last period of ichthyopterygian evolution.

The ichthyopterygian fossil record is more continuous than that of Sauropterygia (compare Figs. 3 and 5) - thus, we have intermediate forms that illustrate the evolution of fish shape from lizard shape. However, as in sauropterygians, many other questions remain concerning the evolution of ichthyopterygians. Even the evolutions of fish shape and sensitive vision are still only vaguely understood. It is necessary to scrutinize the details of anatomical evolution in this group to further our understanding.
Mosasauridae

Unlike the other major groups, mosasaurs are only known from the Late Cretaceous. The oldest mosasauridae is known from the Cenomanian of Israel (about 98 million years ago; Jacobs et al. 2005). There is a small overlap with the stratigraphic range of Ichthyopterygia in the Cenomanian, but no locality is yet known to yield both mosasaurs and ichthyopterygians. They co-occur with plesiosaurs and sea turtles. Mosasaurs most likely became extinct during the $\mathrm{K} / \mathrm{T}$ mass extinction, together with the remaining sauropterygians and many other animals. However, the details are still being discussed. Mosasaurs are known from every continent including Antarctica. Mosasaurs are sometimes referred to as "sea-going monitor lizards" because their skull morphology somewhat resembles that of the genus Varanus (monitor lizards). However, they may not be most closely related to the living monitor lizards. The closest relatives of mosasaurs are other fossil marine reptiles such as aigialosaurs and dolichosaurs, although the exact relationships among these animals are still being debated (Caldwell 2000; Bell and Polcyn 2005; Dutchak 2005). It has been proposed that mosasaurs, aigialosaurs, and dolichosaurs may together be closely related to snakes (see Dutchak 2005 for summary), but a consensus has yet to be reached on this controversial relationship.

Mosasaurs are generally lizard-shaped in body outline, but variations existed in the skeletal design. Limbs of some mosasaurs were paddle-like, with fingers spreading distally, whereas the others had tightly packed fingers that are indicative of flipper-shaped limb that tapers distally, as in Plotosaurus from California (Camp 1942). It has been shown that Plotosaurus also had a specialized tail where vertebrae in different parts of the tail show part-specific patterns of shape (Lindgren et al. 2007). This strongly suggests that the distal part of the tail of Plotosaurus was further specialized as a propulsive organ than in other mosasaurs. It has even been suggested that Plotosaurus had a tail fluke resembling those of some sharks (Lindgren et al. 2007). However, this last claim needs to be scrutinized for at least two reasons. First, the haemal processes in the distal tail are too long in Plotosaurus, unlike in any swimming vertebrates with a tail fluke with vertebral support. Second, Mixosaurus, an ichthyopterygian with enhanced tail segmentation, apparently did not have a fluke, on the basis of an unpublished specimen with tail outline impression.

The most basal Mosasauridae retained the limb design of terrestrial anguimorph squamates and, therefore, were suspected to have spent at least a part of their lives on land (facultative terrestriality: Polcyn and Bell 2005). However, this view was questioned by Caldwell and Palci (2007). The latter authors argued that these basal mosasaurs lacked the sacrum and therefore could not support their body on land. 
They also noted that the close relatives of Mosasuridae within a larger group called Mosasauroidea still retained the sacrum and therefore were facultatively terrestrial.

The reproductive biology of the lineage that led to mosasaurs is at least partly known. Carsosaurus, which is not a true mosasaur but a close relative within Mosasauroidea, is known to have been a live bearer (Caldwell and Palci 2007). As discussed above, these mosasauroids were probably not fully aquatic. It is therefore possible that mosasaurs were already live bearers when they invaded the marine environments. A specimen of a true moasaur with embryos inside the body of an adult is said to exist but still remains undescribed.

Most mosasaurs were generalized feeders, judging from the dentition (Massare 1987). However, some mosasaurs, such as Globidens, had large rounded teeth indicative of durophagy (diet on hard-shelled animals). A recent report of bivalve shells preserved as gut contents of a newly described species of Globidens (Martin and Fox 2007) confirms the prediction from the tooth morphology.

\section{Chelonioidea}

Sea turtles are often overlooked when discussing major Mesozoic marine reptile groups. However, the oldest fossil record of the group comes from the latest Aptian (Lower Cretaceous, about 108 million years ago), and the lineage most likely started even earlier. The oldest known sea turtle Santanachelys was only about 20 centimeters long (Hirayama 1998).

Extant sea turtles are divided into Dermochelyidae (leatherback turtle) and Cheloniidae (the rest). These two lineages were already established in the Cretaceous (Kear and Lee 2006). In addition, there was an extinct lineage called Protostegidae in the Cretaceous. Protostegidae was more closely related to Dermochelyidae than Cheloniidae and included the largest sea turtles ever, such as Archelon (Fig. 1d) that possibly reached four meters in total length (Wieland 1896).

The general lifestyle of Cretaceous sea turtles was probably not very different from that of living forms: they probably had similar feeding and swimming capabilities. One study shows that Notochelone of the Cretaceous fed on bivalve mollusks (Kear 2006). It is important to note that the true sea turtles (Chelonioidea) were not the only turtles that became marine. Prior to the appearance of the sea turtles, at least two groups of turtles are found from marine environments but they did not survive for very long.

\section{Thalattosauria}

Thalattosauria has been an enigmatic group of marine reptiles that is not counted in the four major groups designated earlier in this paper. However, discovery of many complete skeletons from China during the past decade (Rieppel et al. 2000), as well as re-studies of European forms (Müller 2005; Müller et al. 2005), has substantially improved our knowledge. This group is therefore reviewed here as the fifth major group.

Thalattosaurs range at least from the Anisian (Middle Triassic) to the Norian (Late Triassic), which translates to about 40 million years. There is a possibility that some specimens may have come from the Olenekian (Lower Triassic; Nicholls and Brinkman 1993). This appears remarkably shorter than the time range of sauropterygians and ichthyopterygians. However, it has been less than 30 million years since pinnipeds (seals, sea lions, and walruses) invaded the sea (Berta et al. 1989), yet they are very successful in today's coastal water. Therefore, there is no doubt that thalattosaurs were a successful lineage, whereas sauropterygians and ichthyopterygians were exceptionally successful. Thalattosaurs are divided into two lineages (Müller 2007), those with sharp teeth suitable for piscivory (diet on fish) and those with rounded teeth, indicating durophagy (diet on hard-shelled animals). The genus Endennasaurus is edentulous but is thought to belong to the sharp-toothed group (Müller et al. 2005).

Thalattosaurs were medium-sized marine reptiles that were usually two meters or less in total length. However, there is an undescribed specimen that is much larger (up to five meters). Many reptiles tend to have a long tail but the tails of thalattosaurs were very long even for a reptile, sometimes twice as long as the trunk (Fig. 1f). This is in great contrast to pleurosaurs, which had an elongated trunk (Fig. 1g).

Thalattosaurs were cosmopolitan at least in the Northern Hemisphere. They are known from North America (California, Nevada, and British Columbia), China (Guizhou), and southern Europe (Switzerland, Italy, and Austria).

\section{Concluding Remarks}

Different lineages of reptiles invaded marine environments in the Mesozoic, giving rise to at least a dozen groups. The four major groups are Sauropterygia, Ichthyopterygia, Mosasauridae, and Chelonioidea (sea turtles). The longest lasting lineage survived for more than 180 million years, whereas the shortest did not exist beyond a few million years. Mesozoic marine reptiles showed many different adaptations. There were underwater flyers, tuna-like cruisers, as well as typically lizard-like undulatory swimmers. Some fed on hard-shelled animals whereas the others ate fish, cephalopods, and vertebrates, including marine reptiles. Intermediate forms along the evolution of new body plans are best known in Ichthyopterygia, whereas there is a 
large gap in the fossil record for Sauropterygia. The study of Mesozoic marine reptiles is rapidly advancing, with new fossils from China revealing new information on the early evolution of Mesozoic marine reptiles.

Open Access This article is distributed under the terms of the Creative Commons Attribution Noncommercial License which permits any noncommercial use, distribution, and reproduction in any medium, provided the original author(s) and source are credited.

\section{References}

Andrews CW. A descriptive catalogue of the marine reptiles of the Oxford Clay. Based on the Leeds collection in the British Museum (Natural History), London. Part. 1910;1:1-205.

Bardet N. Stratigraphic evidence for the extinction of the ichthyosaurs. Terra Nova. 1992;4:649-56. doi:10.1111/j.1365-3121.1992. tb00614.x.

Bardet N, Fernández MS. A new ichthyosaur from the Upper Jurassic lithographic limestone of Bavaria. J Paleontol. 2000;74:503-11. doi:10.1666/0022-3360(2000)074<0503:ANIFTU>2.0.CO;2.

Bell GL Jr, Polcyn MJ. Dallasaurus turneri, a new primitive mosasauroids from the Middle Turonian of Texas and comments on the phylogeny of Mosasauridae (Squamata). Neth J Geosci. 2005;84:177-94.

Benton MJ. Vertebrate paleontology. 3rd ed. New York: Wiley; 2004. p. 472.

Berta A, Ray CE, Wyss AR. Skeleton of the oldest known pinniped, Enaliarctos mealsi. Science. 1989;244:60-2. doi:10.1126/science. 244.4900 .60

Borden R. Varanus salvator (Asian Water Monitor) migration. Biawak 2007;1:84. Brischoux F, Bonnet X. Cook TR, Shine R. Snakes at sea: diving performances of free-ranging sea kraits. Proceedings of the 11th Annual Meeting on Health, Science and Technology. Université de Tours. 2007.

Brinkmann W. Die Ichthyosaurier (Reptilia) aus der Grenzbitumenzone (Mitteltrias) des Monte San Giorgio (Tessin, Schwiz) - neue Ergebnisse. Vierteljahrsschrift Naturforschenden Ges Zurich. 1998;143:165-77.

Brischoux F, Bonnet X, Cook TR, Shine R. Allometry of diving capacities: ectothermy vs. endothermy. J Evol Biol. 2008;21:324-32.

Caldwell MW. On the aquatic squamate Dolichosaurus longicollis Owen 1850 (Cenomanian, Upper Cretaceous), and the evolution of elongate necks in squamates. J Vertebr Paleontol. 2000;20:720-35. doi:10.1671/0272-4634(2000)020[0720: OTASDL]2.0.CO;2.

Caldwell MW, Palci A. A new basal mosasauroid from the Cenomanian (U. Cretaceous) of Slovenia with a review of mosasauroid phylogeny and evolution. J Vertebr Paleontol. 2007;27:863-80. doi:10.1671/0272-4634(2007)27[863: ANBMFT]2.0.CO;2.

Camp CL. California mosasaurs. Memoirs of the University of California. 1942;13:1-68.

Carroll RL. The emergence of marine reptiles in the Late Paleozoic and Early Mesozoic. In: Reif W-E, Westphal F, editors. Third symposium on mesozoic terrestrial ecosystems, short papers. Tübingen: Attempto; 1982. p. 41-46.

Carroll RL. A pleurosaurs from the Lower Jurassic and the taxonomic position of the Sphenodontida. Palaeontogr Abt A. 1985;189:1-28.
Carroll RL. Vertebrate paleontology and evolution. New York: W. H. Freeman; 1988. p. 698.

Cheng YN, Wu XC, Ji Q. Chinese marine reptiles gave live birth to young. Nature. 2004;423:383-6. doi:10.1038/nature03050.

Dalla Vecchia FM. A new sauropterygian reptile with plesiosaurian affinity from the Late Triassic of Italy. Riv Ital Paleontol Stratigr. 2006;112:207-25.

Dal Sasso C, Pinna G. Besanosaurus leptorhynchus n. gen. n. sp., a new shastasaurid ichthyosaur from the Middle Triassic of Besano (Lombardy, N. Italy). Paleontol Lomb. 1996;4:3-23.

Druckenmiller PS, Russell AP. A phylogeny of Plesiosauria (Sauropterygia) and its bearing on the systematic status of Leptocleidus Andrews, 1922. Zootaxa. 2008;1863:3-120.

Dutchak AR. A review of the taxonomy and systematics of aigialosaurs. Neth J Geosci. 2005;84:221-9.

Fernández MS. Dorsal or ventral? Homologies of the forefin of Caypullisaurus (Ichthyosauria: Ophthalmosauria). J Vertebr Paleontol. 2001;22:515-20. doi:10.1671/0272-4634(2001)021 [0515:DOVHOT]2.0.CO;2.

Fraas E. Ueber einen neuen Fund von Ichthyosaurus in Württemberg. Neues Jahrb Mineral Geol Palaontol. 1892;2:87-90.

Giles J. Mystery and myth behind the plesiosaur. Nature. 2006;441:390. doi:10.1038/441390a.

Graham JB. Body temperatures of the sea snake Pelamis platurus. Copeia. 1974;1974:531-533.

Graham JB, Rubinoff I, Hecht MK. Temperature physiology of the sea snake Pelamis platurus: an index of its colonization potential in the Atlantic Ocean. Proc Natl Acad Sci U S A. 1971;68:1360-3. doi:10.1073/pnas.68.6.1360.

Hesselbo SP, Robinson S, Surlyk F. Sea-level change and facies development across potential Triassic-Jurassic boundary horizons, SW Britain. J Geol Soc Lond. 2004;161:365-79.

Hirayama R. Oldest known sea turtle. Nature. 1998;392:705-8. doi: $10.1038 / 33669$.

Hua S, de Buffrenil V. Bone histology as a clue in the interpretation of functional adaptations in the Thalattosuchia (Reptilia, Crocodylia). J Vertebr Paleontol. 1996;16:703-17.

Jacobs LL, Ferguson K, Polcyn MJ, Rennison C. Cretaceous d13C stratigraphy and the age of dolichosaurs and early mosasaurs. Neth J Geosci. 2005;84:257-68.

Jefferson TA, Leatherwood S, Webber MA. FAO species identification guide. Marine mammals of the world. Rome: FAO; 1993. p. 320.

Jiang DY, Rieppel O, Motani R, Hao WC, Sun YL, Sun ZY. A new Middle Triassic eosauropterygians (Reptilia, Sauropterygia) from southwestern China. J Vertebr Paleontol. 2008;28:1055-62. doi:10.1671/0272-4634-28.4.1055.

Kear BP. First gut content in a Cretaceous sea turtle. Biol Lett. 2006;2:113-5. doi:10.1098/rsbl.2005.0374.

Kear BP, Boles WE, Smith ET. Unusual gut contents in a Cretaceous ichthyosaur. Proc R Soc Lond B Biol Sci. 2003;270:S206-8. doi:10.1098/rsbl.2003.0050.

Kear BP, Lee MSY. A primitive protostegid from Australia and early sea turtle evolution. Biol Lett. 2006;2:116-9. doi:10.1098/ rsbl.2005.0406.

Kozur HW, Bachmann GH. Correlation of the German Triassic with the international scale. Albertiana. 2005;32:21-35.

Kuhn-Schnyder E. Die Triasfauna der Tessiner Kalkalpen. XVIII. Askeptosaurus italicus Nopsca. Schweiz Palaontol Abh. 1952;69:1-73.

Li JL. The horizon and age of the marine reptiles from Hubei Province, China. Vertebrata Palasiatica. 2002;40:241-4.

Li C, Rieppel O. A new cyamodontoid placodont from Triassic of Guizhou. Chin Sci Bull. 2002;47:403-7. doi:10.1360/02tb9094.

Lindgren J, Jagt JWM, Caldwell MW. A fishy mosasaur: the axial skeleton of Plotosaurus (Reptilia, Squamata) reassessed. Lethaia. 2007;40:153-60. 
Martill DM. An ichthyosaur with preserved soft tissue from the Sinemurian of southern England. Palaeontology. 1995;38:897903.

Martin JE, Fox JE. Stomach contents of Globidens, a shell-crushing mosasaur (Squamata), from the Late Cretaceous Pierre Shale Group, Big Bend area of the Missouri River, central South Dakota. Spec Pap Geol Soc Am. 2007;427:167-176.

Massare JA. Tooth morphology and prey preference of Mesozoic marine reptiles. J Vertebr Paleontol. 1987;7:121-37.

Massare JA. Swimming capabilities of Mesozoic marine reptiles; implications for method of predation. Paleobiology. 1988;14:187-205.

McGowan C. A remarkable small ichthyosaur from the Upper Triassic of British Columbia, representing a new genus and species. Can J Earth Sci. 1995;32:292-303.

McGowan C. A new and typically Jurassic ichthyosaur from the Upper Triassic of British Columbia. Can J Earth Sci. 1996;33:24-32.

McGowan C, Motani R. Ichthyopterygia. Handbuch der Paläoherpetologie 8. München: Verlag Dr. Friedrich Pfeil; 2002. p. 175.

Márquez MR. FAO species catalogue. Vol.11: Sea turtles of the world. An annotated and illustrated catalogue of sea turtle species known to date. FAO Fisheries Synopsis No. 125, Vol. 11. Rome: FAO; 1990. p. 81.

Motani R. Scaling effects in caudal fin kinematics: implication for ichthyosaurian speed. Nature. 2002a;415:309-12. doi:10.1038/ 415309a.

Motani R. Swimming speed estimation of extinct marine reptiles: energetic approach revisited. Paleobiology. 2002b;28:251-62. doi:10.1666/0094-8373(2002) 028<0251:SSEOEM>2.0.CO;2.

Motani R. Combining uniformitarian and historical data to interpret how Earth environment influenced the evolution of Ichthyopterygia. Paleontol Soc Pap. 2008;14:147-64.

Motani R, You H, McGowan C. Eel-like swimming in the earliest ichthyosaurs. Nature. 1996;382:347-8. doi:10.1038/382347a0.

Motani R, Rothschild BM, Wahl W Jr. Large eyes in deep diving ichthyosaurs. Nature. 1999;402:747. doi:10.1038/45435.

Müller J. The anatomy of Askeptosaurus italicus from the Middle Triassic of Monte San Giorgio and the interrelationships of thalattosaurs (Reptilia, Diapsida). Can J Earth Sci. 2005;42:1347-67. doi:10.1139/e05-030.

Müller J. The first record of a thalattosaur from the Upper Triassic of Austria. J Vertebr Paleontol. 2007;27:236-40. doi:10.1671/02724634(2007) 27[236:FROATF]2.0.CO;2.

Müller J, Renesto S, Evans S. The marine diapsid reptile Endennasaurus from the Upper Triassic of Italy. Palaeontology. 2005;48:15-30. doi:10.1111/j.1475-4983.2004.00434.x.

Nicholls EL, Brinkman D. New thalattosaurs from the Triassic Sulphur Mountain Formation of Wapiti Lake, British Columbia. J Paleontol. 1993;67:263-78.

Nicholls EL, Manabe M. Giant ichthyosaurs of the Triassic - a new species of Shonisaurus from the Pardonet Formation (Norian: Late Triassic) of British Columbia. J Vertebr Paleontol. 2004;24:838-49. doi:10.1671/0272-4634(2004)024[0838: GIOTTN]2.0.CO;2.
O'Keefe FR. Ecomorphology of plesiosaur flipper geometry. J Evol Biol. 2001;14:987-91. doi:10.1046/j.1420-9101.2001.00347.x.

O'Keefe FR. The evolution of pleisoaur and pliosaur morphotypes in the Plesiosauria (Reptilia: Sauropterygia). Paleobiology. 2002;28:101-12. doi:10.1666/0094-8373(2002)028<0101:TEO $\mathrm{PAP}>2.0 . \mathrm{CO} ; 2$.

O'Keefe FR, Carrano MT. Correlated trends in the evolution of the plesiosaur locomotor system. Paleobiology. 2005;31:656-75.

Polcyn MJ, Bell GL Jr. Russellosaurus coheni n. gen., n. sp., a 92 million-year-old mosasaur from Texas (USA), and the definition of the parafamily Russellosaurina. Neth J Geosci. 2005;84:32133.

Rasmussen AR. Sea snakes. In: Carpenter KE, Niem VH, editors. FAO species identification guide for fishery purposes. The Living Marine Resources of the Western Central Pacific. Volume 6. Bony fishes part 4 (Labridae to Latimeriidae), estuarine crocodiles, sea turtles, sea snakes and marine mammals. Rome: FAO; 2001. p. 3987-4008.

Rieppel O. Sauropterygia I. Handbuch der Paläoherpetologie 12A. München: Verlag Dr. Friedrich Pfeil; 2000. p. 134.

Rieppel O, Liu J, Bucher H. The first record of a thalattosaur reptile from the Late Triassic of southern China (Guizhou Province, PR China). J Vertebr Paleontol. 2000;20:507-14. doi:10.1671/02724634(2000)020[0507:TFROAT]2.0.CO;2.

Rosenzweig PA. Estuarine crocodiles. In: Carpenter KE, Niem VH, editors. FAO species identification guide for fishery purposes. The Living Marine Resources of the Western Central Pacific. Volume 6. Bony fishes part 4 (Labridae to Latimeriidae), estuarine crocodiles, sea turtles, sea snakes and marine mammals. Rome: FAO; 2001. p. 3971-3972.

Scheyer TM. Skeletal histology of the dermal armor of Placodontia: the occurrence of 'postcranial fibro-cartilaginous bone' and its developmental implications. J Anat. 2007;211:737-53. doi:10.1111/j.1469-7580.2007.00815.x.

Seymour RS. Physiological adaptation to aquatic life. In: Gans C, editor. Biology of the Reptilia Vol. 13. Physiology C. London: Academic; 1982. p. 1-51.

Storrs GW. Anatomy and relationships of Corosaurus alcovensis (Diapsida: Sauropterygia) and the Triassic Alcova Limestone of Wyoming. Peabody Mus Nat Hist Bull. 1991;44:1-151.

Tarlo LB. A review of the Upper Jurassic pliosaurs. Bull Br Mus Nat Hist Geol. 1960;4:145-489.

Walls GL. The vertebrate eye and its adaptive radiation. Bloomfield Hills: Cranbrook; 1942.

Whittow GC. Thermoregulatory adaptations in marine mammals: interacting effects of exercise and body mass. A review. Mar Mamm Sci. 1987;3:220-41. doi:10.1111/j.1748-7692.1987.tb00165.x.

Wieland GR. Archelon ischyros: a new gigantic cryptodire testudinate from the Pierre Cretaceous of South Dakota. Am J Sci. 1896;2:399-413.

Wieland GR. Revision of the Protostegidae. Am J Sci. 1909;27:101-31.

Wilfred NT. The occurrence of amphibians and reptiles in saltwater areas, as a bibliography. Bull Mar Sci Gulf Caribb. 1958;8:1-97.

Woodward AS. On two specimens of Ichthyosaurus showing contained embryos. Geol Mag. 1906;5:443-4. 